\title{
Gene Expression Levels of Peripheral Blood Mononuclear Cells IL-6 and TNF- $\alpha$ in Children with Bacterial and Viral Infectious Diarrhea
}

\author{
Peng Xu, Xiaoli Liu, Yanzhen Li, Xuling Yin and Xiaolin Liu
}

\begin{abstract}
Objective: To determine the levels of interleukin-6 (IL-6) and tumor necrosis factor- $\alpha$ (TNF- $\alpha$ ) gene transcription and protein expression in peripheral blood mononuclear cells (PBMCs) of children with bacterial and viral infectious diarrhea. Study Design: An observational study.

Place and Duration of Study: Department of Pediatrics, Pingyi County People's Hospital of Shandong province, Pingyi, China, from January 2017 to February 2018.

Methodology: Children with bacterial diarrhea and children with viral diarrhea were assigned to respective bacterial and viral infection groups. The serum IL-6, TNF- $\alpha$ levels in the two groups were detected by ELISA. PBMCs were collected from study subjects, and mRNA transcription expression level of IL-6 and TNF- $\alpha$ in PBMCs of the two groups were determined by semi-quantitative reverse transcription-polymerase chain reaction (RT-PCR) technique, and IL- 6 and TNF- $\alpha$ protein expression levels in PBMCs of the two groups were determined by Western blot analysis.

Results: In a total of 50 children with bacterial diarrhea and 70 with viral diarrhea, the levels of serum IL-6, PBMCs IL-6 mRNA transcription and IL-6 protein expression were higher in the viral infection group than in the bacterial infection group (all $p<0.001$ ). The level of serum TNF- $\alpha$ and PBMCs TNF- $\alpha$ mRNA transcription and TNF- $\alpha$ protein expression were higher in the bacterial infection group than in the viral infection group (all $p<0.001)$.

Conclusion: When it is difficult to clinically identify the pathogeny of pediatric diarrhea infection, adjuvant diagnosis can be made by virtue of IL- 6 and TNF- $\alpha$ changes in the blood to choose the correct treatment.
\end{abstract}

Key Words: Bacterial infection, Viral infection, Diarrhea, Peripheral blood mononuclear cells, IL-6, TNF- $\alpha$.

\section{INTRODUCTION}

Infectious diarrhea is an acute intestinal infectious disease, which is mainly caused by pathogenic microorganisms and their products or parasites. It is a common pediatric intestinal disease. Viruses and bacteria are the main pathogens causing infectious diarrhea in children.1,2 Where, viral diarrhea is more common in children due to the fact that pediatric digestive system is not yet mature, children with weak self-immunity and resistance are vulnerable to bacterial pathogen attack which causes diarrhea.3,4 The main approach for clinical diagnosis of infectious diarrhea in children is detection of fecal pathogens combining clinical manifestations.5,6 However, due to the similar clinical manifestations of diarrhea caused by different pathogens, the rate of misdiagnosis is relatively high if diagnosis is made based on clinical manifestations, and the detection of fecal pathogens takes a long time with low positive rate. 7,8 This leads to failure to provide timely diagnosis and treatment of acute infectious diarrhea in

Department of Pediatrics, Pingyi County People's Hospital of Shandong Province, Pingyi-273300, China

Correspondence: Xiaolin Liu, Department of Pediatrics,

Pingyi County People's Hospital of Shandong Province,

Pingyi-273300, China

E-mail:pwj7ov@163.com

Received: May 08, 2018; Accepted: July 30, 2018 children, delaying the treatment, and thus bringing about certain negative impact on the growth and development of children. Therefore, rapid and effective diagnostic methods have important significance in the differential diagnosis of acute infectious diarrhea in children. IL- 6 and TNF- $\alpha$, important members of the inflammatory cytokine network, have strong inflammatory activity and can directly act on vascular endothelial cells to increase their permeability, leading to massive exudation from the intestinal wall and then a series of clinical symptoms. 9,10

The purpose of this study was to investigate the differences in the levels of IL- 6 and TNF- $\alpha$ gene transcription and protein expression in PBMCs of children with bacterial and viral infectious diarrhea, to provide reference for early differential diagnosis of infectious diarrhea in children.

\section{METHODOLOGY}

This study was conducted at The Department of Pediatrics of Pingyi County People's Hospital of Shandong province, Pingyi, China, from January 2017 to February 2018. This study inducted 120 children with acute infectious diarrhea as research object. Inclusion criteria were digestive tract infection, bacterial infectious diarrhea children with positive stool cultures, virus infectious diarrhea children with negative stool cultures, and children with positive stool rotavirus. Exclusion 
criteria: children with other bacterial or virus infectious diseases, guardians who refused to take part in the research, children with incomplete data, and revisiting children. The study was conducted after approval from the Hospital Ethical and Research Committee. According to the type of infection and the feces culture, the 50 children with bacterial diarrhea were assigned to bacterial infection group, and the 70 children with viral diarrhea were assigned to viral infection group.

Six $\mathrm{mL}$ venous blood was taken from all subjects on an empty stomach in the early morning. Serum was separated from $1 \mathrm{~mL}$ within one hour. Serum IL-6 and TNF- $\alpha$ concentrations were determined by double antibody sandwich ELISA. Another $5 \mathrm{~mL}$ of venous blood was anticoagulated, and added with lymphocyte separating medium, followed by centrifugation at $2000 \mathrm{r} / \mathrm{min}$ for $20 \mathrm{~min}$ to aspirate mononuclear cell layer. The IL-6 and TNF- $\alpha$ mRNA transcription levels in PBMCs were detected by RT-PCR, and IL-6, TNF- $\alpha$ protein expression level in PBMCs were detected by western blot.

For the main steps of RT-PCR detection, total RNA of PBMCs was extracted by Trizol method and quantified, followed by reverse transcription to synthesize cDNA. RT-PCR detection was performed by PCR instrument with GAPDH, an internal reference. The upstream primer of IL-6 is 5'-CAAATrCGGTA-CATCCTC-3'; and the downstream primer is 5'-CTGGCTYGTYCCTCACTA-3'. The upstream primer of TNF- $\alpha$ is 5'CGAGTGACAAGCCTGTAGC-3' and the downstream primer is 5'-CCTTCTCCAGCTGGAAGAC-3'. The upstream primer of GAPDH is 5'-CCACCACCATCTTCCAGGAG3'; and the downstream primer is 5'-CCTGCTTCACCA CCTTCTTG-3'. The reaction system was $20 \mu \mathrm{L}$. The PCR reaction conditions were pre-denaturation at $94^{\circ} \mathrm{C}$ for three minutes, denaturation at $94^{\circ} \mathrm{C}$ for one minute, annealing at $65^{\circ} \mathrm{C}$ for 30 seconds, extension at $72^{\circ} \mathrm{C}$ for 1 minute, and cycling 30 times at $72^{\circ} \mathrm{C}$ for 10 minutes. The PCR product was electrophoresed on a $2 \%$ agarose gel, stained with ethidium bromide and observed under a UV lamp. The optical density was measured by image system and the ratios of IL-6, TNF- $\alpha$, and GAPDH were calculated. The ratio of optical density was used as the relative level of IL- 6 and TNF- $\alpha$ mRNA.

For the main steps of the Westernblot technique, protein was extracted from PMBC using RIPA protein lysate and protein concentration was determined by Coomassie brilliant blue method. Protein was then separated by $10 \%$ polyacrylamide gel electrophoresis and transferred to the nitrocellulose membrane by electro-transmembrane method, followed by sealing, hybridization, addition of 1:500 goat anti-human IL-6, TNF- $\alpha$ monoclonal antibody and 1:10000 anti-goat IgG antihybridization, ECL reaction, X-ray film tabletting exposure. The integrated optical density analyses results were determined using a gel imaging system with $\beta$-actin as an internal control.

SPSS 21.0 software is adopted for data statistical analysis; measurement data shows in Mean $\pm S D$, examined by independent sample t-test. The $p<0.05$ means there is statistical significance in the difference.

\section{RESULTS}

Among the 120 patients, $68(56.67 \%)$ were males and $52(43.33 \%)$ were females; with age between 2 months and 7 years, average age being $2.83 \pm 0.34$ years. The disease course varied from 2-8 days, the average disease course was $3.56 \pm 0.29$ days.

The levels of serum IL-6, PBMCs IL-6 mRNA transcription and IL-6 protein expression are higher in the viral infection group than in the bacterial infection group (all $\mathrm{p}<0.001$, Table I).

The levels of serum TNF- $\alpha$, PBMCs TNF- $\alpha$ mRNA transcription and TNF- $\alpha$ protein expression are higher in the bacterial infection group than in the viral infection group (all $p<0.001$, Table II).

\section{DISCUSSION}

Infectious diarrhea, if not timely and reasonably treated, will affect the growth and development of children. The gastrointestinal tract not only serves as a digestive organ, but also an important immune organ. Abnormal immune function will cause various gastrointestinal diseases.11,12 Related data show that inflammatory cytokines play a key role in the incidence and development of infectious diarrhea.13,14 Abnormal release of inflammatory cytokines will lead to systemic inflammatory reactions and aggravate immune function imbalance. Increased levels of inflammatory cytokines will further stimulate the inflammatory process, which can easily damage gastrointestinal mucosa barrier

Table I: Comparison of IL-6 indicators in the two groups.

\begin{tabular}{l|c|cc|cc|c}
\hline Group & $\mathrm{n}$ & \multicolumn{2}{|c|}{ Serum IL-6 $(\mathrm{ng} / \mathrm{L})$} & \multicolumn{2}{c|}{ PBMCs IL-6 mRNA transcription } & \multicolumn{2}{c}{ PBMCs IL-6 protein expression } \\
\cline { 3 - 7 } & & Mean \pm SD & $\mathrm{p}$-value & Mean \pm SD & p-value & Mean \pm SD \\
\hline Bacterial infection group & 50 & $97.84 \pm 10.39$ & $<0.001$ & $16.61 \pm 4.07$ & $<0.001$ & $25.26 \pm 4.90$ \\
Viral infection group & 70 & $109.32 \pm 11.42$ & & $24.85 \pm 4.19$ & & $35.03 \pm 2.82$ \\
\hline
\end{tabular}

Table II: Comparison of TNF- $\alpha$ indicators in the two groups.

\begin{tabular}{l|c|cc|cc|c}
\hline Group & $\mathrm{n}$ & \multicolumn{2}{|c|}{ Serum TNF- $\alpha(\mathrm{ng} / \mathrm{L})$} & \multicolumn{2}{|c|}{ PBMCs TNF- $\alpha$ mRNA transcription } & \multicolumn{2}{c}{ PBMCs TNF- $\alpha$ protein expression } \\
\cline { 3 - 7 } & & Mean \pm SD & $p$-value & Mean \pm SD & $p$-value & Mean \pm SD \\
\hline Bacterial infection group & 50 & $209.56 \pm 18.07$ & $<0.001$ & $32.49 \pm 5.75$ & $<0.001$ & $40.16 \pm 8.94$ \\
Viral infection group & 70 & $183.97 \pm 11.42$ & & $27.25 \pm 3.77$ & & $34.82 \pm 5.62$ \\
\hline
\end{tabular}


function, and then lead to multiple organ failure.15,16 Therefore, inflammatory cytokine detection in case of acute infectious diarrhea in children is conducive to understanding of the disease, early diagnosis, and prevention of gastrointestinal dysfunction.

IL-6 is a multifunctional inflammatory cytokine produced by activated $\mathrm{T}$ cells, monocytes, macrophages, fibroblasts, or endothelial cells. ${ }^{17,18}$ Studies have shown that IL-6 levels are positively correlated with severity of bacterial enteritis. ${ }^{19}$ TNF- $\alpha$ is a multifunctional inflammatory cytokine, mainly produced by activated macrophages. Normally, TNF- $\alpha$ has an anti-infective effect, but if it persists or is produced too much, it will participate in the pathogenesis of inflammatory diseases. ${ }^{20,21}$ This study showed that levels of serum IL-6, PBMCs IL-6 mRNA transcription and IL-6 protein expression are higher in the viral infection group than in the bacterial infection group. The levels of serum TNF- $\alpha$, PBMCs TNF- $\alpha$ mRNA transcription and TNF- $\alpha$ protein expression are higher in the bacterial infection group than in the viral infection group. It suggests that the levels of serum IL-6, PBMCs IL-6 mRNA transcription and IL-6 protein expression are significantly elevated in children with viral infectious diarrhea; the levels of serum TNF- $\alpha$, PBMCs TNF- $\alpha$ mRNA transcription and TNF- $\alpha$ protein expression are significantly elevated in children with bacterial infectious diarrhea, which may concern the release of bacteria and endotoxin into the blood and lipopolysaccharide (LPS) stimulation. ${ }^{22}$

\section{CONCLUSION}

IL-6 and TNF- $\alpha$ levels are significantly different between the bacterial and viral infectious diarrhea. TNF- $\alpha$ is increased significantly in case of bacterial infection, and IL-6 is significantly increased in case of viral infection. Hence, when it is not easy to clinically identify the pathogeny of pediatric diarrhea infection, auxiliary diagnosis can be made by virtue of changes in peripheral blood IL- 6 and TNF- $\alpha$ levels to guide selection of the correct treatment plan.

\section{REFERENCES}

1. Roman C, Solh T, Broadhurst M. Infectious diarrhea. Physician Assist Clin 2017; 2:229-45.

2. Chen CC, Huang JL, Chang CJ, Kong MS. Fecal calprotectin as a correlative marker in clinical severity of infectious diarrhea and usefulness in evaluating bacterial or viral pathogens in children. J Pediatr Gastroenterol Nutr 2012; 55:541-7.

3. Koletzko S, Osterrieder S. Acute infectious diarrhea in children. Dtsch Arztebl Int 2009; 106: 539-48.

4. Hong K, Baek SY, Shin JI, Chung KS, Jee YM. Coinfection of viral agents in Korean children with acute watery diarrhea. $J$ Korean Med Sci 2008; 23:937-40.

5. Cleary RK. Clostridium difficile-associated diarrhea and colitis: clinical manifestations, diagnosis, and treatment. Clin Infect Dis 1998; 41:1435-49.

6. Zhang LL, Chen JX. Progress of research on clinical manifestations and diagnosis of human pentastomiasis. Chin $J$ Schistosomiasis Control 2012; 24:222-7.
7. Ramalingam N, Rui Z, Liu HB, Dai CC, Kaushik R, Ratnaharika B, et al. Real-time pcr-based microfluidic array chip for simultaneous detection of multiple waterborne pathogens. Sensors Actuators B Chemical 2010; 145:543-52.

8. Whittier CA, Cranfield MR, Stoskopf MK. Real-time PCR detection of campylobacter spp. in free-ranging mountain gorillas (gorilla beringei beringei). J Wildlife Dis 2010; 46:791-802.

9. Fonsecacamarillo GC, Villedaramírez MA, Sánchezmuñoz F, Barretozúñiga $\mathrm{R}$, Domínguezlópez $\mathrm{A}$, Uribeesquivel $\mathrm{M}$, et al. IL- 6 and TNF- $\alpha$ gene expression in the rectal mucosal of patients with chronic idiopathic ulcerative colitis and controls. Rev De Gastroenterol De Mex 2009; 74:334-40.

10. Colell A, Coll O, Mari M, Fernández-Checa JC, García-Ruiz C. Blockade of endogenous IL-18 ameliorates tnbs-induced colitis by decreasing local TNF- $\alpha$ production. Gastroenterology 2001; 121:1372-9.

11. Ali T, Choe J, Awab A, Wagener TL, Orr WC. Sleep, immunity and inflammation in gastrointestinal disorders. World $\mathrm{J}$ Gastroenterol 2013; 19:9231-9.

12. Khanijow V, Prakash P, Emsellem HA, Borum ML, Doman DB. Sleep dysfunction and gastrointestinal diseases. Gastroenterol Hepatol 2015; 11:817-25.

13. Biesiada G, Czepiel J, Ptak-Belowska A, Targosz A, KrzysiekMaczka G, Strzalka M, et al. Expression and release of leptin and proinflammatory cytokines in patients with ulcerative colitis and infectious diarrhea. J Physiol Pharmacol 2012; 63:471-81.

14. Liu D, Yan C, Xu L, Wang Y, Han W, Zhang X, et al. Diarrhea during the conditioning regimen is correlated with the occurrence of severe acute graft-versus-host disease through systemic release of inflammatory cytokines. Biol Blood Marrow Transplant 2010; 16:1567-75.

15. Xia YL, Chen HW, Wang YC, Xiao HL, Jin SH. Influence of microecological modulators on serum inflammatory factors, intestinal mucosal barrier function, and intestinal flora of patients with acute infectious diarrhea. Chin $J$ Nosocomiol 2016; 26:4844-6.

16. Kim DH, Hwang JS, Lee IH, Nam ST, Ji H, Peng Z, et al. The insect peptide copa3 increases colonic epithelial cell proliferation and mucosal barrier function to prevent inflammatory responses in the gut. J Biol Chem 2016; 291: 3209-23.

17. Chen SM, Lin CP, Tsai JD, Chao YH, Sheu JN. The significance of serum and fecal levels of interleukin- 6 and interleukin-8 in hospitalized children with acute rotavirus and norovirus gastroenteritis. Pediatr Neonatol 2014; 55:120-6.

18. Herlina $\mathrm{H}$, Manoppo JI, Umboh A. Bacterial enteric pathogens and serum interleukin- 6 levels in children with acute diarrhea. Paediatr Indones 2016; 56:144-8.

19. Mangiarotti $P$, Moulin F, Palmer P, Ravilly S, Raymond J, Gendrel D. Interferon-alpha in viral and bacterial gastroenteritis: a comparison with C-reactive protein and interleukin-6. Acta Paediatr 1999; 88:592-4.

20. Lampinen $M$, Carlson $M$, Sangfelt $P$, Taha $Y$, Thõrn $M$, Lõõf $L$, et al. IL-5 and TNF- $\alpha$ participate in recruitment of eosinophils to intestinal mucosa in ulcerative colitis. Dig Dis Sci 2001; 46: 2004-9.

21. Peterson KM, Shu J, Duggal P, Haque R, Mondal D, Jr PW. Association between tnf-alpha and entamoeba histolytica diarrhea. Am J Trop Med Hyg 2010; 82:620-5.

22. Swiergiel AH, Dunn AJ. The roles of IL-1, IL-6, and TNFalpha in the feeding responses to endotoxin and influenza virus infection in mice. Brain Behav Immun 1999; 13:252-65. 